\title{
Determination of Thiram and Aminocarb Pesticides in Natural Water Samples Using Flow Injection with Tris(2,2'-bipyridyl)- ruthenium(II)-diperiodatoargentate(III) Chemiluminescence Detection
}

\author{
Mohammad AsGHAR, * Mohammad YAQOOB, ${ }^{* \dagger}$ Naheed HAQUE, $* *$ and Abdul NABI* \\ *Department of Chemistry, University of Balochistan, Sariab Road, Quetta 87300, Pakistan \\ **Department of Pharmacy, University of Balochistan, Sariab Road, Quetta 87300, Pakistan
}

\begin{abstract}
A simple and sensitive flow-injection (FI) method is reported for the determination of thiram and aminocarb pesticides in natural water samples based on the strong enhancing effects of these pesticides on the tris(2,2'-bipyridyl)ruthenium(II)diperiodatoargentate(III) (Ru(bipy) ${ }_{3}^{2+}$-DPA) chemiluminescence (CL) system. Under the optimum experimental conditions, the CL intensity was linear over the range of $1.0-1000$ and $1.0-10000 \mathrm{ng} \mathrm{mL}^{-1}\left(R^{2}=0.9998(n=7)\right.$ and $0.9994(n=11))$ for thiram and aminocarb, respectively, with relative standard deviations (RSDs; $n=3)$ in the range $1.0-2.6 \%$. The limits of detection $(S / N=3)$ were $0.1 \mathrm{ng} \mathrm{mL}^{-1}$ for both pesticides with injection throughputs of $150 \mathrm{~h}^{-1}$. The key chemical and physical variables (reagent concentrations, flow rates, sample volume, PMT voltage) were optimized and potential interferences investigated. The method was successfully applied to natural water samples and the results obtained were not significantly different (95\% confidence interval) from results obtained by the previously reported FI-CL and HPLC methods. Thiram could be determined in the presence of aminocarb using Triton X-100. The possible CL reaction mechanism is also discussed briefly.
\end{abstract}

Keywords Thiram, aminocarb, natural water, chemiluminescence, flow injection analysis

(Received July 19, 2013; Accepted September 23, 2013; Published November 10, 2013)

\section{Introduction}

Pesticides are chemical or biological substances that are designed to kill or retard the growth of pests that interfere with the growth of crops, shrubs, trees, timber and other vegetation desired by humans. The term pesticide includes substances intended for use as plant growth regulators, defoliants, desiccants or agents for thinning fruit or preventing the premature fall of fruit. Those substances applied to crops either before or after harvest to protect the commodity from deterioration during storage and transport also come under the category of pesticides. ${ }^{1,2}$ However, the application of these compounds and their residues became a problem due to the possibility of contamination of ground and surface water, and a consequent potential impact on the environment and public health. ${ }^{3}$ Therefore, an accurate and efficient monitoring of these pesticides and their residues in water sources and water for human consumption is necessary.

Thiram (tetramethylthiuram disulfide) is a dithiocarbamate compound that is widely used as a fungicide in agriculture for the protection of vegetable crops and seeds, as well as a vulcanizing agent in the rubber industry. Thiram is also present in the environment as an oxidation product of two other widely employed fungicides ferbam and ziram, ${ }^{4}$ and can persist in soil

$\dagger$ To whom correspondence should be addressed.

E-mail: yaqoob2001@hotmail.com for several months. ${ }^{5}$ The maximum residue limits for dithiocarbamates (expressed as carbon disulphide), which are being considered by the European Union, are $2-7 \mathrm{mg} \mathrm{kg}^{-1}$. Aminocarb (4-(dimethylamino)-3-methylphenyl N-methylcarbamate) is a phenylsubstituted methylcarbamate pesticide. It is widely used in agriculture to treat stored grain, fruits and vegetables in order to control a number of insect pests. ${ }^{6,7}$ Figure 1 reports on the chemical structures of thiram and aminocarb pesticides.

Chemiluminescence (CL) is a well-established spectrometric branch of analytical chemistry based on the production of electromagnetic radiation from a chemical reaction. ${ }^{8,9}$ Due to its minimal instrumentation, no external source, simple optical system and high sensitivity and selectivity, CL-based detection has become a useful tool in the liquid phase for the determination of pesticides coupled with flow injection manifolds or HPLC systems. ${ }^{10}$

Diperiodatoargentate(III) (DPA) is a powerful oxidizing agent in an alkaline medium, with a reduction potential of $1.74 \mathrm{~V} .{ }^{11}$ DPA has been used to study the kinetics of the oxidation of various organic substances. ${ }^{11-13}$ Yang and Zhang ${ }^{14}$ have reported a flow-injection (FI)-CL method for the determination of uric acid in human serum based on the reaction of DPA with uric acid in an alkaline medium; it generates a strong CL signal with a detection limit $(3 \sigma)$ of $1.2 \times 10^{-7} \mathrm{~mol} \mathrm{~L}^{-1}$. Yang et al. ${ }^{15}$ have reported an FI-CL method for amikacin sulfate in human serum based on its enhancement effect on a luminol-DPA CL system in an alkaline medium with a detection limit $(3 \sigma)$ of 
<smiles>CN(C)C(=S)SSC(=S)N(C)C</smiles>

Thiram $\left(\mathrm{C}_{6} \mathrm{H}_{12} \mathrm{~N}_{2} \mathrm{~S}_{4} ; \mathrm{MW} .240 .43\right)$

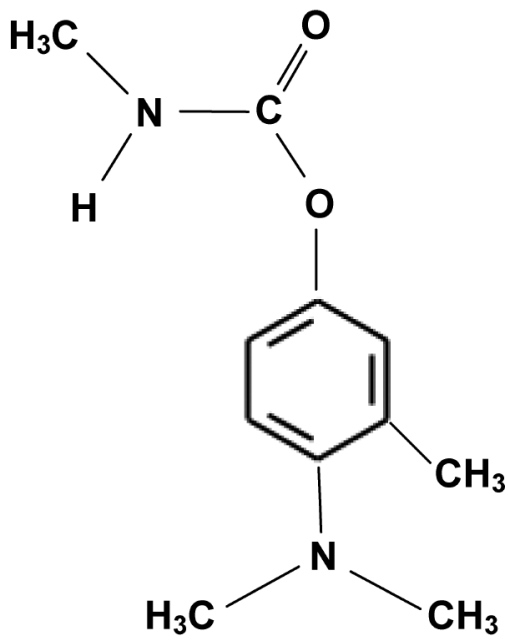

Aminocarb $\left(\mathrm{C}_{11} \mathrm{H}_{16} \mathrm{~N}_{2} \mathrm{O}_{2}, \mathrm{Mw} 208.257\right)$

Fig. 1 Chemical structures of thiram and aminocarb.

$1.9 \times 10^{-8} \mathrm{~mol} \mathrm{~L}^{-1}$. Zhao et al. ${ }^{16}$ have reported another FI-CL method for gemifloxacin in pharmaceutical preparations and biological fluids based on a gemifloxacin-DPA CL reaction in a sulfuric acid medium sensitized by cetyltrimethylammonium bromide with a detection limit $(3 \sigma)$ of $7.3 \times 10^{-10} \mathrm{~g} \mathrm{~mL}^{-1}$.

A limited number of FI-CL methods have been reported for the determination of thiram and aminocarb in natural water samples. Waseem et al. ${ }^{17}$ have reported an FI-CL method for the determination of thiram in natural water samples based on a cerium(IV) sulfate-quinine CL system in aqueous sulfuric acid with a detection limit $(S / N=3)$ of $7.5 \mathrm{ng} \mathrm{mL}^{-1}$ thiram, and a sample throughput of $120 \mathrm{~h}^{-1}$. The same group ${ }^{18}$ also reported another FI-CL method for the determination of maneb, nabam, and thiram in natural water samples based on the photodegradation of these dithiocarbamate fungicides via UV light in an alkaline medium; the produced photoproducts oxidize luminol and generate CL emission. The limits of detection $(S / N=3)$ were $5.0,8.0$ and $10 \mathrm{ng} \mathrm{mL}^{-1}$ for thiram, nabam and maneb, respectively, with a sample throughput of $100 \mathrm{~h}^{-1}$. Girotti et al. ${ }^{19}$ reported a CL-ELISA method for thiram in honeybees; they employed luminol, horseradish peroxidase as a labeling enzyme, and polyclonal antibodies for the detection and quantification of thiram with a detection limit of $9.0 \mathrm{ng} \mathrm{mL}^{-1}$.

The aim of the present study was to establish a simple and sensitive FI-CL method for the determination of thiram and aminocarb. The method is based on the reaction of DPA with $\mathrm{Ru}$ (bipy) $3^{2+}$ generated $\mathrm{Ru}$ (bipy) $3_{3}{ }^{3+}$. Thiram and/or aminocarb reduced the $\mathrm{Ru}(\text { bipy })_{3}{ }^{3+}$ to $\mathrm{Ru}(\text { bipy })_{3}{ }^{2+*}$, which underwent relaxation generating CL. Triton X-100 could be used to determine thiram in the presence of aminocarb.

\section{Experimental}

\section{Reagents and solutions}

All glassware and bottles were cleaned overnight in a nutrient-free detergent ( $2 \% \mathrm{v} / \mathrm{v}$, Neutracon, Decon Laboratories, $\mathrm{UK})$, rinsed with ultra high purity (UHP) water $\left(0.067 \mu \mathrm{S} \mathrm{cm}^{-1}\right.$, Elga, Purelab Option, UK), followed by soaking in $\mathrm{HCl}(10 \%$ $\mathrm{v} / \mathrm{v}$ ) overnight, and again rinsed with UHP water and stored in plastic bags to avoid contamination.

A tris(2,2'-bipyridyl)ruthenium(II) chloride hexahydrate stock solution $\left(0.01 \mathrm{~mol} \mathrm{~L}^{-1}\right)$ was prepared by dissolving $0.374 \mathrm{~g}$ of $\mathrm{Ru}$ (bipy) $3^{2+}$ (Fluka, UK) in $50 \mathrm{~mL}$ of an aqueous solution of $\mathrm{H}_{2} \mathrm{SO}_{4}\left(0.01 \mathrm{~mol} \mathrm{~L}^{-1}\right)$, sonicated for $10 \mathrm{~min}$ and stored in a polyethylene volumetric flask at $4^{\circ} \mathrm{C}$. A working $\mathrm{Ru}(\text { bipy })_{3}{ }^{2+}$ solution $\left(50 \times 10^{-6} \mathrm{~mol} \mathrm{~L}^{-1}\right)$ was prepared by diluting $1.25 \mathrm{~mL}$ of the stock solution to $250 \mathrm{~mL}$ with an aqueous solution of $\mathrm{H}_{2} \mathrm{SO}_{4}\left(0.025 \mathrm{~mol} \mathrm{~L}^{-1}\right)$. A potassium hydroxide stock solution $\left(0.5 \mathrm{~mol} \mathrm{~L}^{-1}\right)$ was prepared by dissolving $2.8 \mathrm{~g}$ of $\mathrm{KOH}$ in a $100-\mathrm{mL}$ polyethylene volumetric flask with UHP water, and stored at $4^{\circ} \mathrm{C}$. Working standards were prepared by diluting the required volume of the stock solution in UHP water.

Stock solutions (100 $\mathrm{mg} \mathrm{L}^{-1}$ ) of thiram, aminocarb, terbufose, thiabendazole, malathion, diazinone, propanil, antu, bendiocarb, aldrin, tridemorph, trimethoprim, maneb, nabam, carbofuran, fenarimol, simetryn, permethrin and dinoseb were prepared by dissolving $10 \mathrm{mg}$ of each pesticide (Dr Ehrenstorfer $\mathrm{GmbH}$, Germany) in $100 \mathrm{~mL}$ of absolute ethanol, sonicated for $10 \mathrm{~min}$ and stored in brown bottles at $4^{\circ} \mathrm{C}$. Working standards of these pesticides were prepared by dilution in ethanol $(0.5 \% \mathrm{v} / \mathrm{v})$ as required. Cation $\left(\mathrm{Na}^{+}, \mathrm{K}^{+}, \mathrm{Ca}^{2+}, \mathrm{Mg}^{2+}, \mathrm{Zn}^{2+}, \mathrm{Cu}^{2+}, \mathrm{Fe}^{2+}, \mathrm{Fe}^{3+}\right.$, $\mathrm{Co}^{2+}$ and $\left.\mathrm{Mn}^{2+}\right)$ and anion $\left(\mathrm{NO}_{3}^{-}, \mathrm{HCO}_{3}{ }^{-}, \mathrm{Cl}^{-}, \mathrm{SO}_{4}{ }^{2-}\right.$, and $\left.\mathrm{PO}_{4}{ }^{3-}\right)$ stock solutions $\left(250 \mathrm{mg} \mathrm{L}^{-1}\right)$ were prepared in UHP water, and subsequent standard solutions of each were prepared by diluting of stock solutions with ethanol $(0.5 \% \mathrm{v} / \mathrm{v})$.

Stock solutions (1\% w/v) of Brij-35 (polyoxyethylene lauryl ether), and Triton X-100 from Research Organic (Cleveland, $\mathrm{OH}$ ), Tween-20 (polyoxyethylene sorbitan monolaurate) from Bio-Rad Laboratories (Hercules, CA), CTAB (cetyltrimethylammonium bromide) from MP Biomedicals (Solon, $\mathrm{OH}$ ) and SDS (sodium dodecyl sulfate) were prepared by dissolving $0.1 \mathrm{~g}$ of each surfactant in $10 \mathrm{~mL}$ of UHP water, and stored in brown bottles at room temperature. Working standards of each surfactant were prepared by dilution in ethanol $(0.5 \% \mathrm{v} / \mathrm{v})$.

DPA was prepared according to a procedure reported previously. ${ }^{20}$ The UV-visible spectrum of DPA exhibited two absorption peaks at 253 and $362 \mathrm{~nm}$, identical to those reported previously. ${ }^{14,20}$ The DPA solutions were freshly prepared by dissolving an amount of the compound in a $0.05 \mathrm{~mol} \mathrm{~L}^{-1} \mathrm{KOH}$ solution before use; the concentration was then determined by the absorbency at $362 \mathrm{~nm}$ (molar absorptivity $\varepsilon=1.26 \times 10^{4}$ $\left.\mathrm{mol}^{-1} \mathrm{~L} \mathrm{~cm}^{-1}\right)^{21}$ using a double-beam UV-vis spectrophotometer (Shimadzu, Model UV-1700, Japan). 


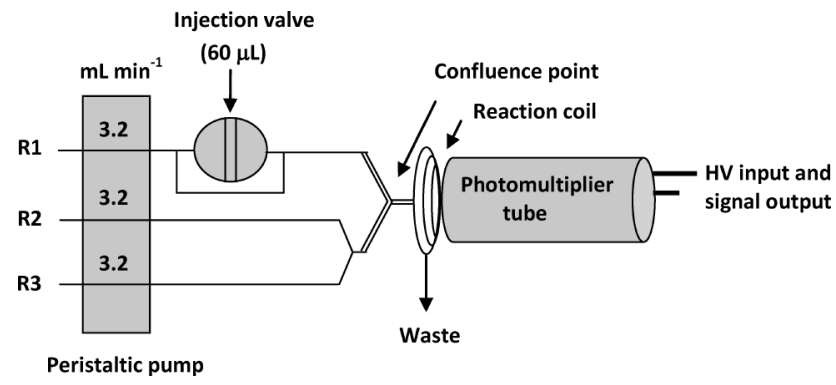

Fig. 2 FIA-CL manifold for the determination of thiram and aminocarb: R1, ethanol solution $(0.5 \% \mathrm{v} / \mathrm{v}) ; \mathrm{R} 2, \mathrm{Ru}(\mathrm{bipy})_{3}{ }^{2+}$ solution $\left(50 \times 10^{-6} \mathrm{~mol} \mathrm{~L}^{-1}\right)$ in $\mathrm{H}_{2} \mathrm{SO}_{4}\left(0.025 \mathrm{~mol} \mathrm{~L}^{-1}\right) ; \mathrm{R} 3$, DPA solution $\left(60 \times 10^{-6} \mathrm{~mol} \mathrm{~L}^{-1}\right)$ in $\mathrm{KOH}\left(0.05 \mathrm{~mol} \mathrm{~L}^{-1}\right)$.

\section{Flow injection manifold and procedure}

The flow injection system used in this work is shown in Fig. 2. A peristaltic pump (Ismatec, Switzerland) was used to deliver flow streams, each at a flow rate of $3.2 \mathrm{~mL} \mathrm{~min}^{-1}$. PTFE tubing (0.8 mm i.d., Fischer, UK) was used as connection material in the flow system. Standard or sample solutions of thiram and/or aminocarb were injected into an ethanol $(0.5 \% \mathrm{v} / \mathrm{v})$ carrier stream using a six-way injection valve (Rheodyne 5020, Anachem, Luton, UK) equipped with a sample loop $(60 \mu \mathrm{L})$, merged with $\mathrm{Ru}$ (bipy) $)_{3}{ }^{2+}\left(50 \times 10^{-6} \mathrm{~mol} \mathrm{~L}^{-1}\right)$ in an aqueous $\mathrm{H}_{2} \mathrm{SO}_{4}$ solution $\left(0.025 \mathrm{~mol} \mathrm{~L}^{-1}\right)$ and oxidant DPA $\left(60 \times 10^{-6} \mathrm{~mol} \mathrm{~L}^{-1}\right)$ in an aqueous $\mathrm{KOH}$ solution $\left(0.05 \mathrm{~mol} \mathrm{~L}^{-1}\right)$ stream at a T-piece. These were allowed to pass through a glass spiral flow cell $(1.5 \mathrm{~mm}$ i.d., $18 \mathrm{~mm}$ diameter $)$ positioned in front of an end window photomultiplier tube (9798B, Electron Tubes Ltd., Ruislip, UK). The PMT, glass coil and T-piece were enclosed in a light-tight housing. The PMT was kept at $800 \mathrm{~V}$ via a $2 \mathrm{KV}$ power supply (Electron Tubes, PM30D, Ruisilip, UK). The detector output was recorded using a chart recorder (BD 40, Kipp \& Zonen, Holland).

\section{Samples collection and solid-phase extraction procedure}

The proposed method was applied to the determination of thiram and aminocarb in natural water samples. Water samples were collected from various locations of Quetta valley in acid washed $(\mathrm{HCl}, 10 \% \mathrm{v} / \mathrm{v})$, high-density polyethylene bottles, filtered through a cellulose membrane filter (pore size, $0.45 \mu \mathrm{m}$; Whatman, Maidstone, UK) to remove suspended particles. The samples were stored in the dark at $4{ }^{\circ} \mathrm{C}$ until analysis.

The spiked samples were extracted by solid phase-extraction (SPE) using Sep-Pak $\mathrm{C}_{18}$ cartridges (Waters Associates, USA), which were conditioned with UHP water $(5.0 \mathrm{~mL})$ and ethanol $(5.0 \mathrm{~mL})$, and then air-dried for over $2 \mathrm{~min} .{ }^{22}$ Each sample was passed through a SPE cartridge under a vacuum at a flow rate of $10 \mathrm{~mL} \mathrm{~min}^{-1}$. After a retention step, the cartridges were washed with UHP water $(0.5 \mathrm{~mL})$, and then dried by passing air for $10 \mathrm{~min}$. Elutions of the retained pesticides were achieved with absolute ethanol $(5.0 \mathrm{~mL})$, and then the organic phase was brought to near dryness under a nitrogen stream. The residue was re-dissolved in an appropriate volume of ethanol $(0.5 \% \mathrm{v} / \mathrm{v})$, sonicated for $5 \mathrm{~min}$ and injected into the proposed FI-CL manifold.

\section{Results and Discussion}

\section{Kinetics curve of the CL reaction}

The kinetic characteristics of the proposed CL reaction were

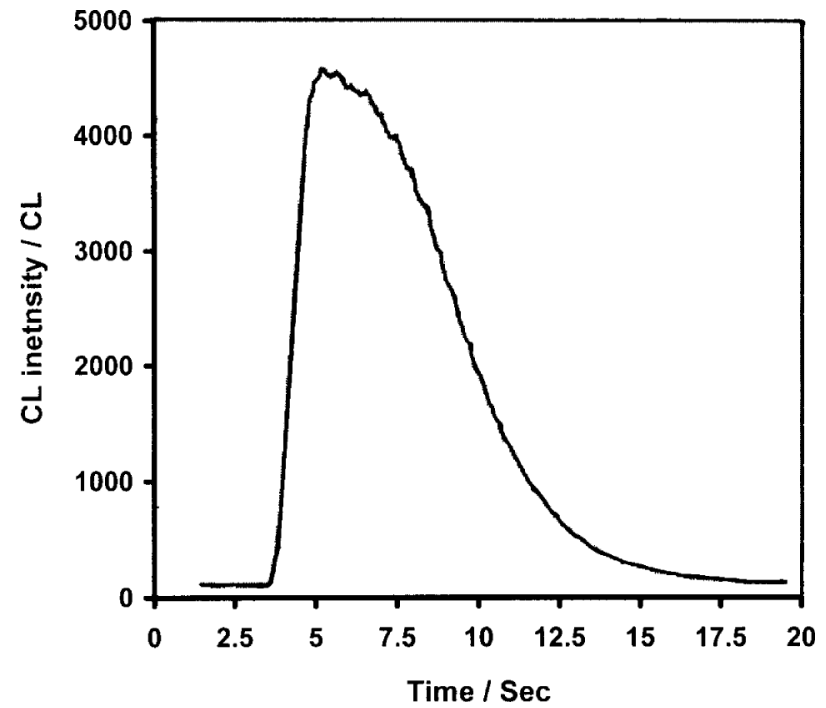

Fig. 3 CL kinetic curve of $\mathrm{Ru}(\text { bipy })_{3}{ }^{2+}-\mathrm{DPA}$ catalyzed by thiram: $\mathrm{Ru}(\text { bipy })_{3}{ }^{2+}$ solution $\left(50 \times 10^{-6} \mathrm{~mol} \mathrm{~L}^{-1}\right)$ in $\mathrm{H}_{2} \mathrm{SO}_{4}\left(0.025 \mathrm{~mol} \mathrm{~L}^{-1}\right)$; DPA solution $\left(60 \times 10^{-6} \mathrm{~mol} \mathrm{~L}^{-1}\right)$ in $\mathrm{KOH}\left(0.05 \mathrm{~mol} \mathrm{~L}^{-1}\right)$; thiram standard solution $\left(1.5 \mu \mathrm{g} \mathrm{mL}^{-1}\right)$ in ethanol $(0.5 \% \mathrm{v} / \mathrm{v})$.

studied by using the batch method. In the batch mode, the experimental parameters were kept constant; the typical response curve (intensity $v s$. times) of the Ru(bipy) $3^{2+}$-DPA CL reaction enhanced by thiram with respect to time is shown in Fig. 3. The result demonstrates that the CL intensity increased rapidly at $c a$. $3 \mathrm{~s}$ after the thiram solution was injected, and reached a maximum in $c a .6 \mathrm{~s}$. The intensity became weaker, and was almost at the base line after $18 \mathrm{~s}$. The kinetic curve indicated that the CL system was rapid, sensitive enough and suitable for performing the determination of thiram and aminocarb.

\section{Optimization studies}

To establish the optimum manifold conditions for the determination of thiram and aminocarb pesticides, the effects of the key chemical and physical variables on the analytical signal were investigated using an univariate approach. The variables include $\mathrm{H}_{2} \mathrm{SO}_{4}, \mathrm{Ru}(\text { bipy })_{3}{ }^{2+}, \mathrm{KOH}, \quad \mathrm{DPA}$ and ethanol concentrations, the flow rates of all streams, the sample injection volume, the reaction coil length and the PMT voltage for maximum CL emission. All studies were performed with thiram and aminocarb $\left(0.1 \mu \mathrm{g} \mathrm{mL}^{-1}\right)$ standard solutions, a sample volume of $60 \mu \mathrm{L}$ and a PMT voltage of $1000 \mathrm{~V}$. All measurements were performed in triplicate.

\section{Effect of $\mathrm{H}_{2} \mathrm{SO}_{4}$ on the $\mathrm{CL}$ intensity}

The efficiency of $\mathrm{Ru}(\text { bipy })_{3}{ }^{2+} \mathrm{CL}$ is dependent on the acidic conditions. The effect of different acids $\left(\mathrm{HCl}, \mathrm{HNO}_{3}, \mathrm{H}_{3} \mathrm{PO}_{4}\right.$ and $\mathrm{H}_{2} \mathrm{SO}_{4}$ ) on the $\mathrm{CL}$ intensity, used as diluent for a $\mathrm{Ru}(\text { bipy })_{3}{ }^{2+}$ solution, was examined. The results showed that the maximum $\mathrm{CL}$ signal was attained with $\mathrm{H}_{2} \mathrm{SO}_{4}$. The effect of different concentrations of $\mathrm{H}_{2} \mathrm{SO}_{4}$ over the range of $0.001-0.1 \mathrm{~mol} \mathrm{~L}^{-1}$ was studied. It was observed that the $\mathrm{CL}$ intensity increased with increasing $\mathrm{H}_{2} \mathrm{SO}_{4}$ concentration, and reached the maximum value at $0.025 \mathrm{~mol} \mathrm{~L}^{-1}$. Therefore, a $\mathrm{H}_{2} \mathrm{SO}_{4}$ concentration of $0.025 \mathrm{~mol} \mathrm{~L}^{-1}$ was selected for subsequent experiments.

\section{Effect of Ru(bipy) ${ }_{3}{ }^{2+}$ on the CL intensity}

The effect of the $\mathrm{Ru}$ (bipy) ${ }_{3}{ }^{2+}$ concentration was examined over the range of $1.0-100 \times 10^{-6} \mathrm{~mol} \mathrm{~L}^{-1}$ using the optimized $\mathrm{H}_{2} \mathrm{SO}_{4}$ 


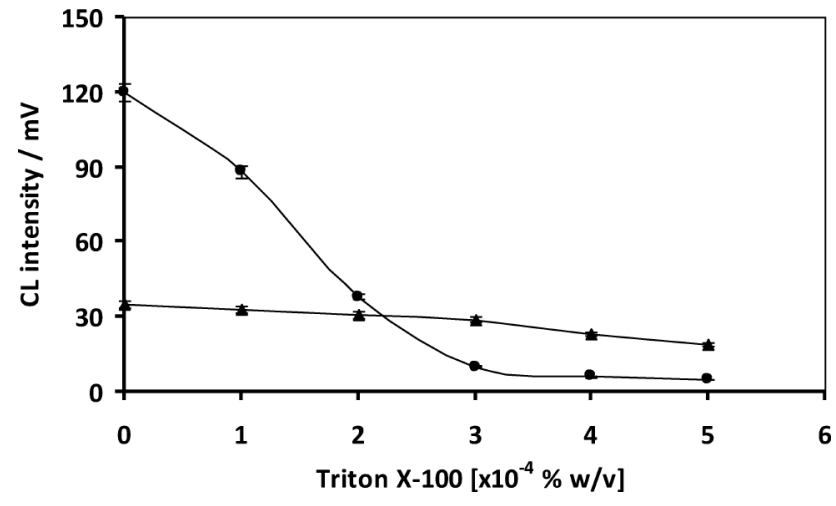

Fig. 4 Effect of the Triton X-100 concentration on the CL intensity of thiram $\left(0.01 \mu \mathrm{g} \mathrm{mL}^{-1}\right.$, triangle $)$ and aminocarb $\left(0.2 \mu \mathrm{g} \mathrm{mL}^{-1}\right.$, circle $)$ standard solutions. Experimental conditions: sample volume, $60 \mu \mathrm{L}$; flow rate, $3.2 \mathrm{~mL} \mathrm{~min}^{-1}$; $\mathrm{Ru}$ (bipy) ${ }_{3}{ }^{2+}$ solution $\left(50 \times 10^{-6} \mathrm{~mol} \mathrm{~L}^{-1}\right)$ in $\mathrm{H}_{2} \mathrm{SO}_{4},\left(0.025 \mathrm{~mol} \mathrm{~L}^{-1}\right)$; PMT voltage, $800 \mathrm{~V}$.

conditions $\left(0.025 \mathrm{~mol} \mathrm{~L}^{-1}\right)$. The increase in the $\mathrm{Ru}(\text { bipy })_{3}{ }^{2+} \mathrm{CL}$ reagent concentration resulted in a steep increase up to $50 \times 10^{-6} \mathrm{~mol} \mathrm{~L}^{-1}$, above which the background response increased, causing a decrease in the CL intensity. Therefore, a $\mathrm{Ru}$ (bipy) ${ }_{3}^{2+}$ concentration of $50 \times 10^{-6} \mathrm{~mol} \mathrm{~L}^{-1}$ was selected and used in all further experiments.

\section{Effect of DPA and $\mathrm{KOH}$ on the CL intensity}

In the proposed CL reaction, DPA acts as an oxidant, the concentration of which affects not only the CL sensitivity, but also the linearity of the method. The effect of the DPA concentration on the CL intensity was examined over the range of $7.0-85 \times 10^{-6} \mathrm{~mol} \mathrm{~L}^{-1}$. The results showed that the CL intensity increased with an increase in the DPA concentration up to $60 \times 10^{-6} \mathrm{~mol} \mathrm{~L}^{-1}$, above which the CL intensity decreased. Therefore, a DPA concentration of $60 \times 10^{-6} \mathrm{~mol} \mathrm{~L}^{-1}$ was selected and used subsequently. Yang et al..$^{14}$ reported that the DPA complex at low concentration is not stable in UHP water, while Blaikungeri et al. ${ }^{20}$ reported that this reagent is insoluble in concentrated $\mathrm{KOH}$. Keeping in view both of these properties for DPA, the effect of the $\mathrm{KOH}$ concentration over the range of $0.001-0.1 \mathrm{~mol} \mathrm{~L}^{-1}$ was examined. The optimal $\mathrm{KOH}$ concentration was $0.05 \mathrm{~mol} \mathrm{~L}^{-1}$, and therefore, a $\mathrm{KOH}$ concentration of $0.05 \mathrm{~mol} \mathrm{~L}^{-1}$ was selected and used subsequently. The $\mathrm{pH}$ value of the waste solution ( $\mathrm{Ru}(\mathrm{bipy}) 3^{2+}$ in $\mathrm{H}_{2} \mathrm{SO}_{4}\left(0.025 \mathrm{~mol} \mathrm{~L}^{-1}\right)$ and DPA in $\left.\mathrm{KOH}\left(0.05 \mathrm{~mol} \mathrm{~L}^{-1}\right)\right)$ was 2.71, using a $\mathrm{pH}$ meter (3305, Jenway Ltd. Felsted, Dunmow, Essex, UK).

\section{Effect of ethanol on the CL intensity}

Thiram and aminocarb stock solutions were prepared in absolute ethanol. It is well known that organic solvents in general influence the CL behavior; therefore, the effect of the ethanol concentration on the CL intensity was studied over the range of $0.01-5 \%(\mathrm{v} / \mathrm{v})$. The maximum $\mathrm{CL}$ intensity was observed at $0.5 \%$ of the ethanol concentration, and a further increase in the ethanol concentration resulted in a non-reproducible CL signal with high background. Therefore, an ethanol concentration of $0.5 \%(\mathrm{v} / \mathrm{v})$ was selected and used as a sample carrier stream.

\section{Effect of surfactants on the CL intensity}

The effect of various surfactants, including CTAB, SDS, Brij-35, Tween-20 and Triton X-100, in the range of
Table 1 Analytical figures of merit of thiram and aminocarb pesticides (the detection limit is based on blank + 3SD)

\begin{tabular}{lcc}
\hline \multicolumn{1}{c}{ Parameters } & Thiram & Aminocarb \\
\hline $\begin{array}{l}\text { Linear range/ng mL } \\
\text { Limit of detection } / \mathrm{ng} \mathrm{mL}^{-1}\end{array}$ & $1.0-1000$ & $1.0-10000$ \\
Calibration equation & 0.1 & 0.1 \\
$(I=$ intensity $(\mathrm{mV})$, & $I=2533 C+3.5822$ & $I=598.6 C+14.992$ \\
$C=$ concentration & & \\
$\left.\left(\mathrm{ng} \mathrm{mL} \mathrm{mL}^{-1}\right)\right)$ & & \\
Blank signal $/ \mathrm{mV}$ & 0.7 & 0.5 \\
Coefficient of determination & $0.9998(n=7)$ & $0.9994(n=11)$ \\
$\left(R^{2}\right)$ & $1.3-2.6$ & $1.0-2.3$ \\
RSD range, $\%(n=4)$ & 150 & 150 \\
Injection throughput $/ \mathrm{h}^{-1}$ & & \\
\hline
\end{tabular}

$1-5 \times 10^{-4 \%}(\mathrm{w} / \mathrm{v})$ on the blank (in the absence of thiram and/or aminocarb) and on the determination of thiram and aminocarb was examined. Among all of these surfactants, CTAB was found to inhibit the CL of both pesticides, while Triton $\mathrm{X}-100$ was found to inhibit the aminocarb CL in the presence of thiram. The inhibiting effect of Triton X-100 on the determination of aminocarb was investigated, as shown in Fig. 4. The CL signal of aminocarb was almost quenched by Triton X-100, possibly due to a strong interaction between Triton X-100 and aminocarb. The CL signal from thiram remained almost unchanged in the presence of Triton X-100 at $3 \times 10^{-4} \%(\mathrm{w} / \mathrm{v})$, while aminocarb CL was quenched at $>90 \%$, which means that Triton $\mathrm{X}-100$ could be used while determining thiram in the presence of aminocarb, CL reactions in the presence of surfactants. In micellar media we showed that sensitized and quenched CL could arise due to solubilization and altering the $\mathrm{pH}$ of the microenvironment ${ }^{23,24}$ for electrostatic attraction.

\section{Effect of the physical parameters on the CL intensity}

The effect of the flow rates for each of the three channels was simultaneously examined over the range of $0.5-5.0 \mathrm{~mL} \mathrm{~min}{ }^{-1}$ in terms of the sensitivity, sample throughput and reagent consumption. A flow rate of $3.2 \mathrm{~mL} \mathrm{~min}^{-1}$ gave the maximum CL intensity with a steady baseline and reproducible CL signals, and was selected and used for all streams. Similarly, the effect of the sample volume on the sensitivity of the flow system over the range of $30-150 \mu \mathrm{L}$ was examined. A sample injection volume of $60 \mu \mathrm{L}$ was used for economy of the sample consumption and the speed of response, respectively. The effect of the PMT voltage over the range of $700-1000 \mathrm{~V}$ was optimized for the maximum CL signal-to-noise ratio. The CL emission increased linearly with the PMT voltage, but $800 \mathrm{~V}$ was used for all subsequent studies, which gave the best signal-to-noise ratio.

\section{Analytical characteristics}

The analytical figures of merit for the proposed FI-CL method, i.e., the linear dynamic range, precision, limit of detection and injection throughput, using the optimized experimental conditions, are given in Table 1. The limits of detection, based on $S / N=3$ (i.e., the concentration giving a mean response that was three-times the peak-to-peak baseline noise because the matrix blank gave no detectable response above the baseline) was $0.1 \mathrm{ng} \mathrm{mL}^{-1}$ of thiram and aminocarb with injection throughputs of $150 \mathrm{~h}^{-1}$, respectively. 
Table 2 Results of recovery tests of thiram and aminocarb in natural water samples $(n=3)$

\begin{tabular}{clrrrrr}
\hline \multirow{2}{*}{ Sample } & \multicolumn{3}{c}{$\begin{array}{c}\text { Spiked/ } \\
\mu g \mathrm{~mL}^{-1}\end{array}$} & $\begin{array}{c}\text { Proposed FIA-CL } \\
\text { method recovery, } \%\end{array}$ & & \multicolumn{2}{c}{$\begin{array}{c}\text { Reported method } \\
\text { recovery, } \%\end{array}$} \\
\cline { 3 - 4 } \cline { 6 - 7 } & & Thiram & Aminocarb & & Thiram $^{18}$ & Aminocarb $^{25}$ \\
\hline \multirow{2}{*}{ Tap water } & 0.075 & $103 \pm 2$ & $104 \pm 3$ & & $97 \pm 2$ & $98 \pm 4$ \\
& 0.15 & $98 \pm 4$ & $102 \pm 4$ & & $101 \pm 4$ & $100 \pm 2$ \\
Irrigation & 0.075 & $99.5 \pm 3$ & $98 \pm 5$ & & $98 \pm 3$ & $96 \pm 2$ \\
water & 0.15 & $96.5 \pm 2$ & $101 \pm 2$ & & $100 \pm 2$ & $98 \pm 4$ \\
& 0.25 & $105 \pm 1$ & $95.8 \pm 4$ & & $95 \pm 3$ & $97 \pm 5$ \\
Lake water & 0.075 & $95 \pm 4$ & $102 \pm 3$ & & $98 \pm 5$ & $105 \pm 3$ \\
& 0.15 & $98 \pm 2$ & $96 \pm 6$ & & $102 \pm 2$ & $100 \pm 5$ \\
& 0.25 & $106 \pm 2$ & $103 \pm 4$ & & $95 \pm 4$ & $97 \pm 2$ \\
\hline
\end{tabular}

\section{Interference study}

Under the optimal experimental conditions, the effect of several pesticides and some common anions and cations at environmentally relevant concentrations was examined on the blank (in the absence of thiram and/or aminocarb) and on the determination of thiram $\left(0.025 \mu \mathrm{g} \mathrm{mL}^{-1}\right)$ and aminocarb $\left(0.05 \mu \mathrm{g} \mathrm{mL}^{-1}\right)$. Propanil, bendiocarb, aldrin, tridemorph, carbofuran, fenarimol, simetryn, permethrin and dinoseb pesticides (40-fold) had no significant effect on the blank, or on the determination of aminocarb and thiram. However, nabam (0.5-fold) had a slight enhancing effect on both the CL signal blank and on the thiram and aminocarb response.

The effect of different cations and anions was examined on the blank (in the absence of thiram and aminocarb), and on the determination of thiram and aminocarb. The tolerance limit of foreign species was taken as the concentration that caused a relative error of less than $\pm 5 \%$ in the CL intensity. No interference could be found with $\mathrm{Na}^{+}\left(100 \mu \mathrm{g} \mathrm{mL}^{-1}\right), \mathrm{K}^{+}$ $\left(40 \mu \mathrm{g} \mathrm{mL}^{-1}\right), \mathrm{Ca}^{2+}\left(75 \mu \mathrm{g} \mathrm{mL}^{-1}\right), \mathrm{Mg}^{2+}\left(50 \mu \mathrm{g} \mathrm{mL}^{-1}\right), \mathrm{PO}_{4}{ }^{3-}$ $\left(1.0 \mu \mathrm{g} \mathrm{mL}^{-1}\right), \mathrm{SO}_{4}{ }^{2-}\left(250 \mu \mathrm{g} \mathrm{mL}^{-1}\right), \mathrm{Cl}^{-}\left(100 \mu \mathrm{g} \mathrm{mL}^{-1}\right), \mathrm{NO}_{3}{ }^{-}$ $\left(10 \mu \mathrm{g} \mathrm{mL}^{-1}\right)$ and $\mathrm{HCO}_{3}^{-}\left(25 \mu \mathrm{g} \mathrm{mL}^{-1}\right) . \mathrm{Fe}^{2+}, \mathrm{Mn}^{2+}, \mathrm{Co}^{2+}$ (at $1.0 \mu \mathrm{g} \mathrm{mL}^{-1}$ each) had an enhancing effect on both the $\mathrm{CL}$ signal blank and on thiram and aminocarb. The effect of cations e.g., $\mathrm{Fe}^{2+}, \mathrm{Co}^{2+}$ and $\mathrm{Mn}^{2+}$, can be masked online with $\mathrm{Na}_{2}$-EDTA, and could be easily removed from natural water samples during SPE extraction.

\section{Validation of the proposed method}

In order to evaluate the validity of the proposed method, the concentration of thiram and aminocarb was determined in natural water samples. All of the water samples were spiked with $0.075,0.15$ and $0.25 \mu \mathrm{g} \mathrm{mL}^{-1}$ of thiram and aminocarb within the linear range of the methods, respectively. After using the SPE procedure (described above), the samples were injected into the proposed FI-CL system. The results are given in Table 2. The results obtained by the proposed method were matched with the reported FI-CL ${ }^{18}$ and HPLC ${ }^{25}$ methods with \% recovery in the range of $95 \pm 3-106 \pm 2 \%$ for thiram and $95 \pm 5-105 \pm 3 \%$ for aminocarb, respectively. They were in good agreement with these reported methods.

\section{CL reaction mechanism}

Since the emergence of $\mathrm{Ru}(\text { bipy })_{3}{ }^{2+}$ as a CL reagent, ${ }^{26}$ $\mathrm{Ru}(\text { bipy })_{3}{ }^{2+}$ has found many applications for pharmaceuticals and pesticides. The methodology relies upon the fundamental sequence of reaction presented below: (i) $\mathrm{Ru}(\text { bpy })_{3}{ }^{2+} \rightarrow \mathrm{Ru}(\text { bpy })_{3}{ }^{3+}+\mathrm{e}^{-}$(oxidation),

(ii) $\mathrm{Ru}(\mathrm{bpy})_{3}{ }^{3+} \rightarrow\left[\mathrm{Ru}(\mathrm{bpy})_{3}{ }^{2+}\right]^{*}$ (reduction with analyte),

(iii) $\left[\mathrm{Ru}(\mathrm{bpy})_{3}{ }^{2+}\right]^{*} \rightarrow \mathrm{Ru}(\mathrm{bpy})_{3}{ }^{2+}+\mathrm{h} v$ (CL emission).

Chemical oxidation can be achieved by using concentrated $\mathrm{HNO}_{3}, \mathrm{PbO}_{2}, \mathrm{Ce}(\mathrm{IV})$ and $\mathrm{Cl}_{2} .{ }^{27} \mathrm{Ru}$ (bipy) $)_{3}{ }^{2+}$ with $\mathrm{Ce}(\mathrm{IV})$ as an oxidizing agent has been applied for the determination of antibiotics of the fluoroquinolones family. ${ }^{28}$ Pharmaceuticals/pesticides containing nitrogen in their chemical structure (heterocyclic compounds/amines) have been used as reductants to produce orange emission, and hence detected by the $\mathrm{Ru}(\mathrm{II})$ complex. ${ }^{29,30}$

Recently, transition metals, such as $\mathrm{Ag}(\mathrm{III}), \mathrm{Ni}(\mathrm{IV})$ and $\mathrm{Cu}$ (III), stabilized by chelating with polydentate ligands, have been exploited in CL systems as oxidizing agents. Emission is brought about by energy released in a redox reaction on which the oxidant or reductant species are the metal complex and a CL reagent. DPA is a powerful oxidizing agent, and has been used for the oxidation of various organic and inorganic species. ${ }^{11,31,32}$ DPA played a strong oxidizing role with luminol, and some drugs were capable of enhancing the CL reaction. ${ }^{15}$

In the present study, the maximum CL in the presence and absence of thiram and aminocarb containing nitrogen appeared at a $610 \mathrm{~nm}$, and a much higher CL peak was observed in the presence of thiram and aminocarb, indicating that $\mathrm{Ru}$ (II) is the luminophore. DPA is used as an oxidizing agent for generating $\mathrm{Ru}$ (bipy) $3^{3+}$, thiram and aminocarb as reductant enhancing $\mathrm{CL}$ emission.

\section{Conclusions}

The proposed FI-CL method for the determination of thiram and aminocarb in natural water samples is simple; has low limits of detection $(S / N=3) 0.1 \mathrm{ng} \mathrm{mL}^{-1}$ and high injection throughputs $\left(150 \mathrm{~h}^{-1}\right)$. The results obtained by the proposed method were close to that of the FI-CL and HPLC methods with \% recovery in the range of $95 \pm 3-106 \pm 2 \%$ for thiram and $95 \pm 5-105 \pm 3 \%$ for aminocarb, respectively. Triton X-100 thiram could be selectively determined in the presence of aminocarb. The low limits of detection, good precision (RSD $<3.0 \%$ ), high injection throughput, low reagents concentration and easy manifold to assemble and operate, all compare favorably with previously reported flow-based methods. In addition, DPA can be readily prepared and stable in alkaline media.

\section{Acknowledgements}

The authors are grateful to the Higher Education Commission, Pakistan for financial support in the form of an Indigenous Ph.D. Scholarship (PIN 117-6914-PS7-156) and the Department of Chemistry, University of Balochistan for providing laboratory facilities.

\section{References}

1. International code of conduct on the distribution and use of pesticides, hundred and twenty-third session of the FAO Council, November 2002.

2. R. Bhadekar, S. Pote, V. Tale, and B. Nirichan, Am. J. Anal. Chem., 2011, 2, 1.

3. E. Ballesteros and M. J. Parrado, J. Chromatogr., A, 2004, 
1029, 267.

4. K. W. Lowen, J. Assoc. Off. Agric. Chem., 1961, 44, 584.

5. C. A. Edwards, "Persistent Pesticides in the Environment", 1981, CRC Press, Boca Raton, FL.

6. K. M. S. Sundaram, N. Boyonoski, and R. W. Wing, $J$. Environ. Sci. Health, Part B, 1987, 22, 565.

7. Y. N. Ni, W. Q. Xiao, and S. Kokot, J. Hazard. Mater., 2009, 168, 1239 .

8. A. M. G. Campana and W. R. G. Baeyens, "Chemiluminescence in Analytical Chemistry", 2001, Marcel Dekker, New York.

9. Y. Su, H. Chen, Z. Wang, and Y. Lv, Appl. Spectrosc. Rev., 2007, 42, 139.

10. L. G. Gracia, A. M. G. Campana, J. J. S. Chinchilla, J. F. H. Perez, and A. G. Casado, TrAC, Trends Anal. Chem., 2005, 24, 927.

11. K. A. Thabaj, S. A. Chimatadar, and S. T. Nandibewoor, $J$. Mol. Struct., 2008, 882, 88.

12. V. Seregar, T. M. Veeresh, and S. T. Nandibewoor, Polyhedron, 2007, 26, 1731.

13. T. M. Veeresh and S. T. Nandibewoor, J. Chem. Thermodyn., 2008, 40, 284

14. C. Yang and Z. Zhang, Talanta, 2010, 81, 477.

15. C. Yang, Z. Zhang, and J. Wang, Luminescence, 2010, 25, 36

16. F. Zhao, W. H. Zhao, and W. Xiong, Luminescence, 2013, 28,108 .

17. A. Waseem, M. Yaqoob, and A. Nabi, Luminescence, 2010, 25,71 .

18. A. Waseem, M. Yaqoob, and A. Nabi, Anal. Sci., 2009, 25 ,
395.

19. S. Girotti, E. Maiolini, S. Ghini, E. Ferri, and F. Fini, Anal. Lett., 2008, 41, 46.

20. A. Blaikungeri, M. Pelletter, and D. Monnier, Inorg. Chim. Acta, 1977, 22, 7.

21. A. Blaikungeri and M. Pelletier, Inorg. Chim. Acta, 1978 , 29, 141.

22. R. M. Maggio, P. C. Damiani, and A. C. Olivieri, Talanta, 2011, 83, 1173.

23. G.-F. Zhang and H.-Y. Chen, Anal. Chim. Acta, 2000, 409, 75

24. R. Chong, J.-E. R. Rho, H.-J. Yoon, P. S. Park, T.-H. D. Rho, J. Y. Park, L. Park, Y.-H. Kim, and J. H. Lee, Talanta, 2013, 116, 403.

25. K. M. S. Sundaram, J. Liq. Chromatogr. Relat. Technol., 1997, 20, 1423.

26. D. M. Hercules and F. E. Lytle, J. Am. Chem. Soc., 1966, $88,4745$.

27. M. Iranifam, Luminescence, 2012, published in Wiley Online Library, DOI 10.1002/bio.2441.

28. J. A. Murillo, A. Al. Molina, A. M. de la Peña, I. D. Merás, and A. J. Girón, J. Fluoresc., 2007, 17, 481.

29. R. D. Gerardi, N. W. Barnett, and S. W. Lewis, Anal. Chim. Acta, 1999, 378, 1.

30. B. A. Gorman, P. S. Francis, and N. W. Barnett, Analyst, 2006, 131, 616.

31. P. J. Rao, B. Sethuram, and T. N. Rao, React. Kinet. Catal. Lett., 1985, 29, 289.

32. P. K. Jaiswal and K. L. Yadava, Talanta, 1970, 17, 236 